Klaudia SZKODA-POLISZUK ${ }^{1}$

DOI: https://doi.org/10.53052/9788366249875.03

\title{
WALIDACJA RUCHOMOŚCI ORAZ PARAMETRÓW MECHANICZNYCH MODELU NUMERYCZNEGO ODCINKA LĘDŹWIOWEGO KRĘGOSEUPA
}

\begin{abstract}
Streszczenie: W pracy przedstawiono walidację ruchomości oraz ciśnienia wewnątrzdyskowego modelu numerycznego odcinka lędźwiowego kręgosłupa. Proces walidacji miał na celu sprawdzenie stopnia zgodności przyjętych założeń modelu numerycznego, odwzorowującego biomechanikę odcinka lędźwiowego kręgosłupa, do rzeczywistych warunków eksperymentalnych. Walidację przeprowadzono dla trzech przypadków obciążenia: ściskania, zginania (do przodu) i przeprostu (zginania do tyłu).
\end{abstract}

Słowa kluczowe: odcinek lędźwiowy, walidacja, metoda elementów skończonych, biomechanika kręgosłupa

\section{VALIDATION OF MOBILITY AND MECHANICAL PROPERTIES OF FINITE ELEMENT MODEL OF LUMBAR SPINE}

\begin{abstract}
Summary: The article presents a validation of the mobility and intradiscal pressure of the numerical model of the lumbar spine. The validation process was aimed at verifying the compliance with the assumptions adopted by the numerical model with the experimental conditions. Validation was carried out for three load cases.
\end{abstract}

Keywords: lumbar spine, validation, finite element method, spine biomechanics

\section{Wprowadzenie}

Obecnie w literaturze istnieje wiele prac dotyczących analiz różnych zagadnień biomechanicznych kręgosłupa rozpatrywanych przy użyciu metody elementów skończonych (MES). W zależności od analizowanej struktury kręgosłupa przyjmowane są liniowe lub nieliniowe parametry materiałowe tkanek miękkich oraz kostnych a także można zaobserwować, że prezentowane modele różnią się często między sobą dokładnością odwzorowania geometrii kręgosłupa [1, 2, 3, 4].

${ }^{1}$ dr inż., Politechnika Wrocławska, Wydział Mechaniczny, Katedra Mechaniki, Inżynierii Materiałowej i Biomedycznej, klaudia.szkoda-poliszuk@pwr.edu.pl 
Pożądanym aspektem w analizach numerycznych jest przede wszystkim to, aby modele w jak największym stopniu odwzorowywały obiekty rzeczywiste. Dzięki walidacji tworzonych modeli numerycznych $\mathrm{z}$ wynikami otrzymanymi na drodze badań doświadczalnych, coraz częściej analizy numeryczne są uzupełnieniem, a zarazem rozszerzeniem eksperymentów prowadzonych w laboratorium. Ogromną zaletą analiz numerycznych jest przede wszystkim to, że powalają na zaobserwowanie zjawisk zachodzących wewnątrz struktur kręgosłupa, których często nie można przeanalizować podczas wykonywania badań doświadczalnych. W przypadku odcinka lędźwiowego istnieje wiele badań doświadczalnych i numerycznych skupiających się na wyznaczeniu parametrów mechanicznych opisujących ten odcinek kręgosłupa.

W celu porównania przygotowanego rozwiązania MES $\mathrm{z}$ danymi doświadczalnymi przeprowadzono walidację modelu numerycznego. Proces walidacji miał na celu sprawdzenie stopnia zgodności (poprawności) przyjętych założeń modelu numerycznego, odwzorowującego biomechanikę odcinka lędźwiowego kręgosłupa, do rzeczywistych warunków eksperymentalnych. Walidacja modelu numerycznego odbyła się poprzez porównanie wyników $\mathrm{Z}$ symulacji numerycznych $\mathrm{Z}$ wynikami otrzymanymi na drodze badań doświadczalnych.

\section{Materiał i metoda}

\subsection{Model geometryczny}

Przestrzenny (3D) model geometryczny odcinka lędźwiowego (L1-L5) zbudowano na podstawie wymiarów kręgosłupa, uzyskanych $\mathrm{z}$ analizy obrazów tomografii komputerowej (CT) (Rysunek 1). Badanie CT wykonano dwóm mężczyzną w wieku 40-50 lat, u których nie występowały zmiany w obrębie układu kostno-stawowego kręgosłupa. Dwuwymiarowe obrazy przekroi kręgosłupa od L1 do L5 zaimportowano do programu InVesalius, w którym stworzono modele 3D kręgów [5]. Wartości poszczególnych wymiarów parametrycznych kręgów uwzględnionych w modelu numerycznym zweryfikowano $\mathrm{z}$ wymiarami kręgów przedstawianych w literaturze [6]. Dodatkowo na podstawie modelu uzyskanego z obrazowania CT zmierzono położenie oraz kąt nachylenia poszczególnych kręgów w stosunku do osi długiej kręgosłupa w celu odwzorowania geometrii odcinka lędźwiowego. 


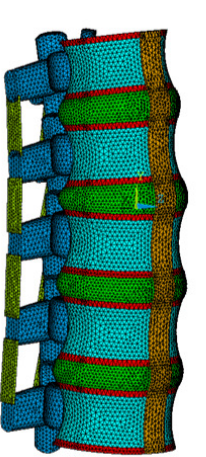

Płaszczyzna strzałkowa

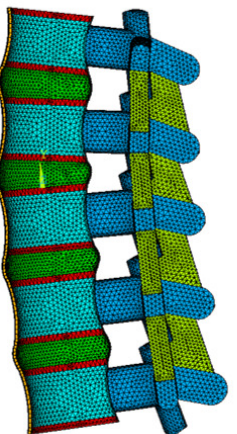

Płaszczyzna czołowa

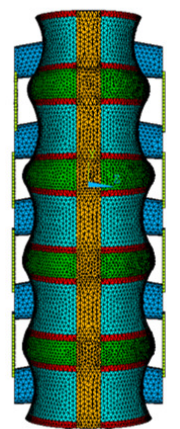

Rysunek 1. Model odcinka lędźwiowego kręgostupa (L1-L5)

Model geometryczny odcinka lędźwiowego (L1-L5) stworzony został w programie ANSYS Mechanical APDL 18.2. Oprócz kręgów w modelu odtworzona została również geometria krążków międzykręgowych, płytek granicznych oraz systemu więzadeł. Grubość płytki granicznej zamodelowano jako 10\% wysokości trzonu kręgu. W modelu uwzględniono szczegółową budowę krążka międzykręgowego. Przyjęto, nie tylko, zróżnicowanie pomiędzy obszarem jądra miażdżystego a pierścieniem włóknistym, ale także różnice pomiędzy warstwami zewnętrznymi, środkowymi i wewnętrznymi samego pierścienia włóknistego. Poszczególne komponenty modelu składające się na pojedynczy segment ruchowy odcinka lędźwiowego kręgosłupa przedstawiono na Rysunek 2.

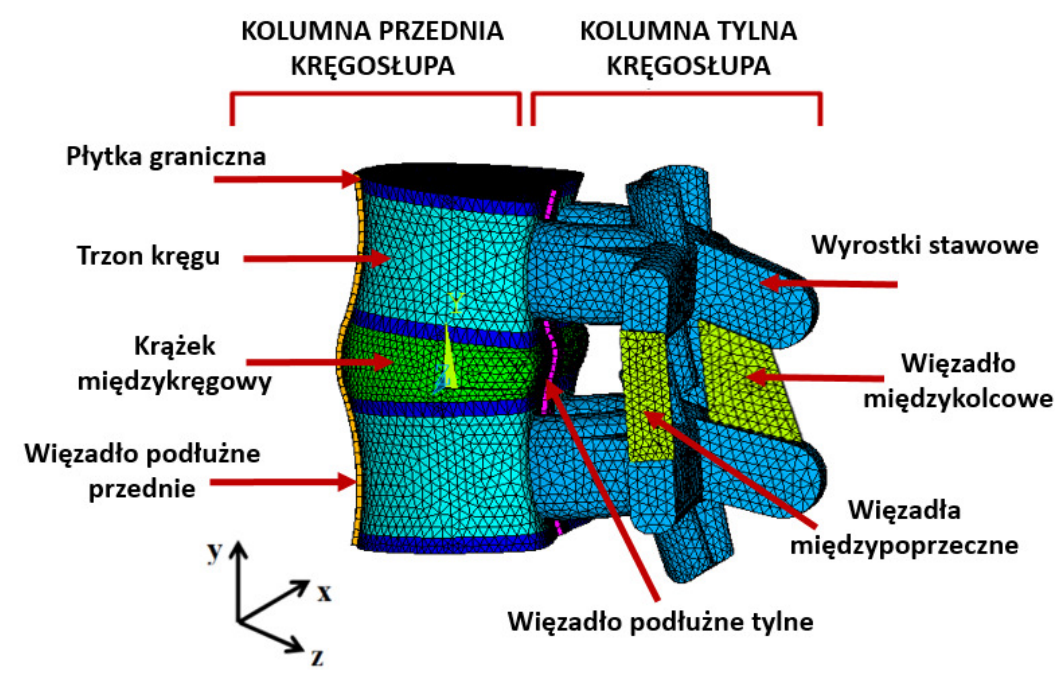

Rysunek 2. Komponenty modelu segmentu ruchowego kręgostupa

\subsection{Model dyskretny}

Zamodelowane kręgi oraz krążki międzykręgowe w modelu dyskretnym opisano 10-węzłowymi, tetraedrycznymi elementami bryłowymi typu SOLID 187. Każdy 
z trzonów kręgów zamodelowano jako kość gąbczastą otoczoną warstwą kości korowej o grubości w zakresie $0.5 \div 1 \mathrm{~mm}$. We wszystkich kręgach uwzględniono także występowanie płytek granicznych (górnych i dolnych). W macierzy pierścienia włóknistego zamodelowano trzy cylindrycznie ułożone warstwy włókien kolagenowych używając 4-węzłowych elementów powłokowych typu SHELL 181 o sześciu stopniach swobody w każdym węźle. Elementy te przeznaczone są głównie do modelowania materiałów wielowarstwowych. Pozwalają one na odwzorowanie właściwości materiałów kompozytowych dzięki temu, że poszczególnym warstwom można nadać odmienną grubość, parametry materiałowe oraz orientację włókien. Włókna w poszczególnych warstwach krążka międzykręgowego pochylone zostały pod kątem $30^{\circ}$ oraz zorientowane naprzemiennie tzn. prawostronnie bądź lewostronnie. Wszystkie cztery główne grupy więzadeł występujących w kręgosłupie (więzadło podłużne przednie, więzadło podłużne tylne, więzadła międzykolcowe, więzadła międzypoprzeczne) zamodelowano również jako 4-węzłowe element powłokowe typu SHELL 181.

\subsection{Dobór parametrów materiałowych modelu}

Tkankę kostną kręgów i płytki graniczne opisano izotropowymi, liniowo-sprężystymi właściwościami materiałowymi [1-4]. Krążek międzykręgowy zamodelowano zgodnie z modelem krążka zaproponowanym przez Schmidt i wsp. [7], który strukturę pierścienia włóknistego zamodelował jako macierz wzmocnioną warstwami włókien kolagenowych. Jądro miażdżyste wraz z macierzą pierścienia włóknistego opisano nieliniowymi właściwościami materiałowymi stosując model hipersprężysty Mooney-Rivlin [7]. Warstwom włókien nadano izotropowe, nieliniowe właściwości materiałowe [1-4]. Z kolei więzadła opisane zostały izotropowymi, liniowo-sprężystymi właściwościami materiałowymi [1]. Jednocześnie na powierzchniach wyrostków stawowych wprowadzono elementy kontaktu typu powierzchnia-powierzchnia (o współczynniku tarcia wynoszącym 0.1). Przyjęte właściwości materiałowe poszczególnych struktur tkankowych przedstawiono w Tabeli 1.

Tabela 1. Właściwości materiałowe poszczególnych komponentów odcinka lędźwiowego kręgostupa [1, 2, 3, 4]

\begin{tabular}{lcc} 
Kość zbita & $\begin{array}{c}\text { Moduł Younga } \\
{[\mathrm{MPa}]}\end{array}$ & $\begin{array}{c}\text { Współczynnik } \\
\text { Poisson’a [-] }\end{array}$ \\
\hline Kość gąbczasta & 12000 & 0,3 \\
\hline Wyrostki stawowe & 100 & 0,2 \\
\hline Płytka granicza & 3500 & 0,25 \\
\hline Jądro miażdżyste & 25 & 0,1 \\
\hline Macierz pierścienia włóknistego & $\begin{array}{c}\text { Hipersprężysty } \\
\text { (Mooney-Rivlin) }\end{array}$ & 0,499 \\
\hline c $_{1}=0,12, c_{2}=0,09$ & 0,45 \\
Warstwy pierścienia włóknistego & $\begin{array}{c}\text { Hiperspręzsty } \\
\text { (Mooney-Rivlin) }\end{array}$ & \\
\hline$c_{1}=0,56, c_{2}=0,14$ & 0,45 \\
\hline
\end{tabular}




\begin{tabular}{lll} 
warstwa 1 & 495 & \\
warstwa 2 & 440 & \\
warstwa 3 & & 0,3 \\
\hline Więzadło podłużne przednie & 20 & 0,3 \\
\hline Więzadło podłużne tylne & 50 & 0,3 \\
\hline Więzadla międzykolcowe & 12 & \\
Więzadła międzypoprzeczne & & \\
\hline
\end{tabular}

\subsection{Warunki obciążenia modelu}

Walidację przeprowadzono dla trzech przypadków obciążenia: ściskania, zginania (do przodu) i przeprostu (zginanie do tyłu). W każdym w przypadków obciążenie przyłożone zostało do powierzchni górnej płytki granicznej trzonu kręgu L1. Ponadto modele zamocowane zostały poprzez odjęcie wszystkich stopni swobody węzłom na powierzchni dolnej płytki granicznej trzonu kręgu L5 (Rysunek 3). W przypadku ściskania przeanalizowano wyniki otrzymane dla obciążenia wywołanego siłą równą $300 \mathrm{~N}$ oraz $500 \mathrm{~N}$. Natomiast w przypadku zginania i przerostu symulacje przeprowadzono pod działaniem momentem siły równego 2,5 Nm, 5,0 Nm oraz 7,5 Nm. Uzyskane wyniki porównane zostały z wynikami eksperymentalnymi i numerycznymi przedstawionymi w literatura przez: Andersson i wsp. [8], Wilke i wsp. [9], Sato i wsp. [10], Rohlmann i wsp. [11], Wood i wsp. [12], Xu i wsp. [3], Brinckmann i Grootenboer [13] oraz Panjabi i wsp. [14]. Parametrami wybranymi do walidacji było ciśnienie wewnątrzdyskowe oraz zakres ruchomości kątowej poszczególnych segmentów.

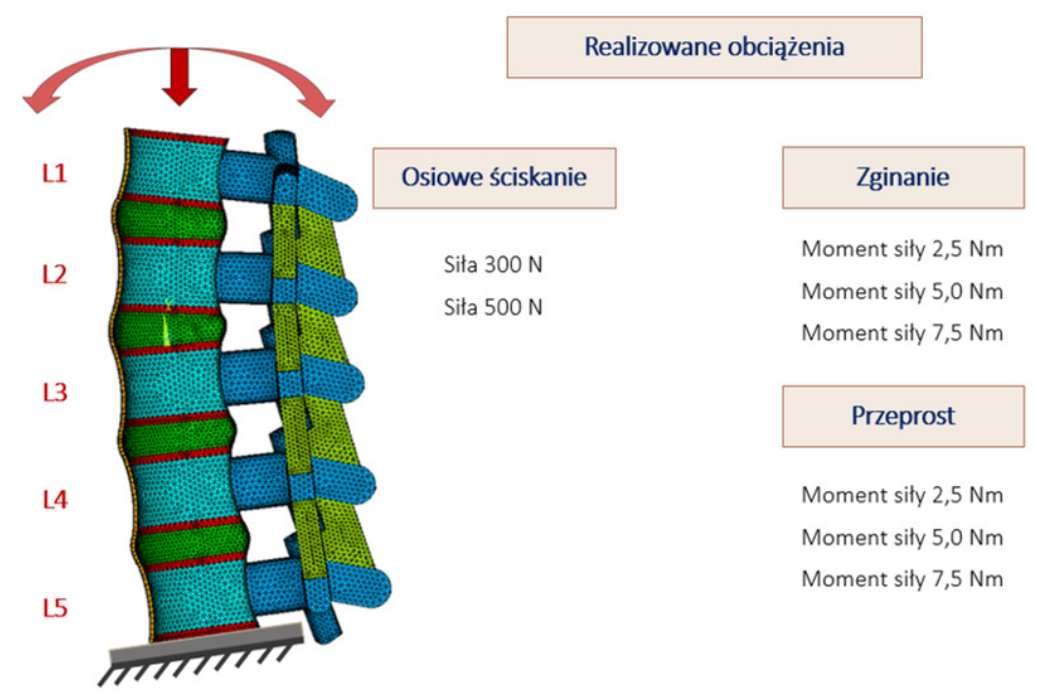

Rysunek 3. Schemat obciążenia i mocowania modelu odcinka lędźwiowego kregostupa 


\section{Wyniki}

\section{1 Ściskanie}

W pierwszym etapie analizy walidacji poddano wartości ciśnienia wewnątrzdyskowego oraz zakresu ruchomości kątowej poszczególnych segmentów ruchowych otrzymane dla obciążenia ściskającego równego $500 \mathrm{~N}$. Otrzymane wyniki $\mathrm{w}$ porównaniu $\mathrm{z}$ literaturowymi wynikami otrzymanymi na drodze badań doświadczalnych (in vivo) i numerycznych wskazują na podobieństwo pomiędzy wartościami uzyskanymi przez różnych autorów [8-11]. W przypadku ciśnienia wewnątrz dyskowego największa różnica pomiędzy wynikami wynosiła 17\% (Rysunek 4).

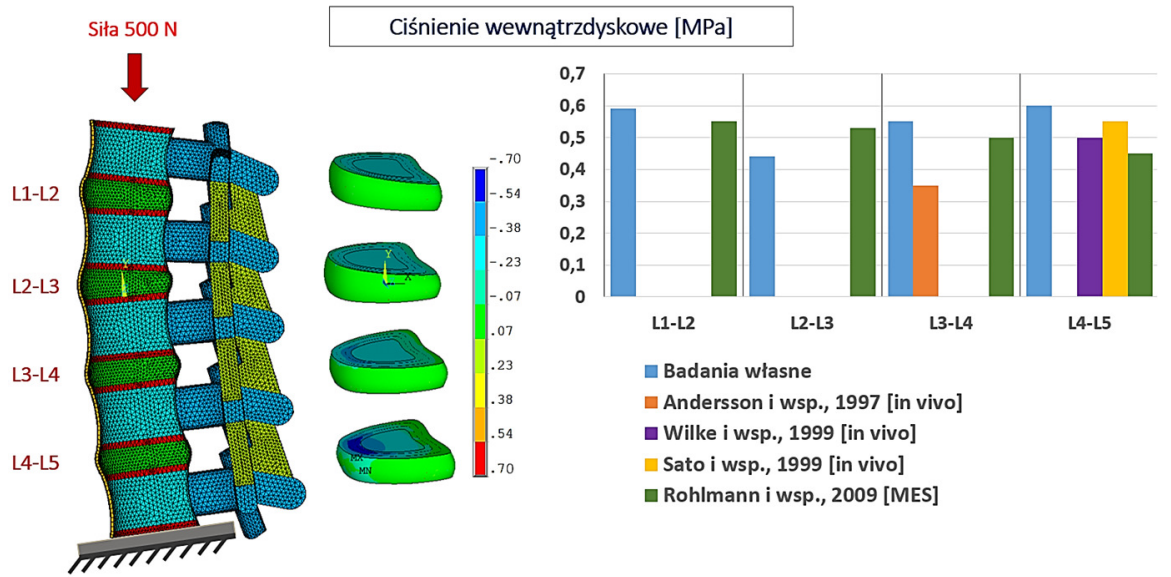

Rysunek 4. Porównanie wartości ciśnienia wewnatrzdyskowego z danymi literaturowymi w przypadku ściskania sita $500 \mathrm{~N}$

Z kolei w przypadku zakresu ruchomości kątowej poszczególnych segmentów ruchowych uzyskane wyniki były zbliżone do wyników uzyskanych przez Rohlmann i wsp. [11]. Znaczącą różnice między wynikami zauważono w przypadku segmentu L1-L2. Badania in vivo wykazały ruchomość w zakresie $0,5^{\circ}$, natomiast badania numeryczne wartość równą 3,6 (Rysunek 5). 


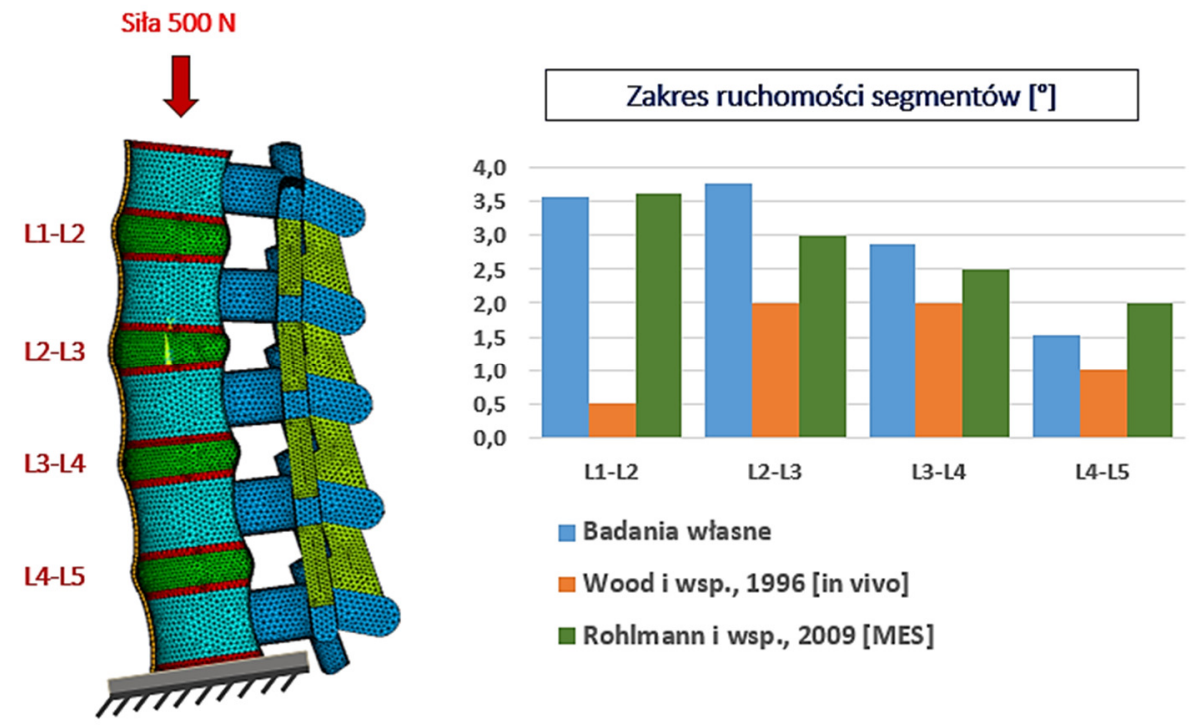

Rysunek 5. Porównanie wartości zakresu ruchomości kątowej poszczególnych segmentów z danymi literaturowymi w przypadku ściskania sita $500 \mathrm{~N}$

W drugim etapie walidacji przeanalizowano wartości ciśnienia wewnątrzdyskowego segmentu ruchowego L4-L5 dla obciążenia ściskającego równego $300 \mathrm{~N}$ (Rysunek 6). Walidacja wykazała, że w tym przypadku otrzymane wartości są porównywalne z wynikami przedstawianymi w literaturze [3, 13].

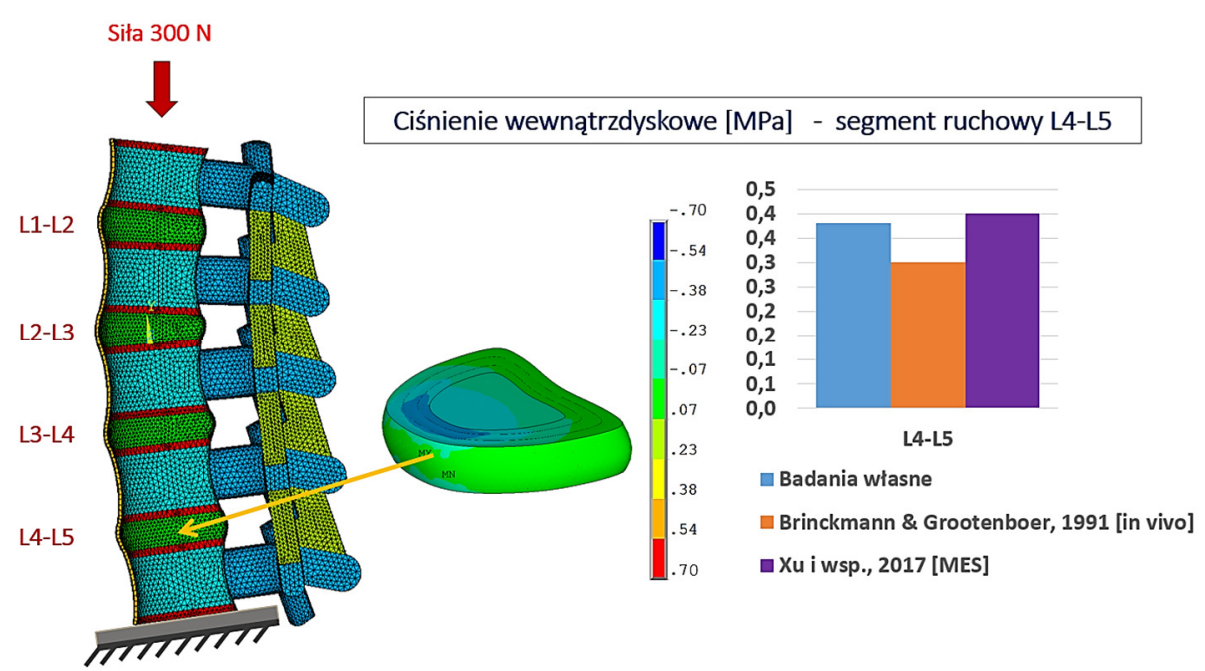

Rysunek 6. Porównanie wartości ciśnienia wewnątrzdyskowego z danymi literaturowymi w przypadku ściskania siła $300 \mathrm{~N}$ 


\subsection{Zginanie i przeprost}

W kolejnym etapie przeanalizowano wartości zakresu ruchomości kątowej poszczególnych segmentów ruchowych otrzymane w przypadku zginania i przeprostu pod działaniem momentem siły równego 2,5 Nm, 5,0 Nm oraz 7,5 Nm. Porównanie uzyskanych wyników z danymi literaturowymi [3, 14] przedstawiono na Rysunkach 7-10.
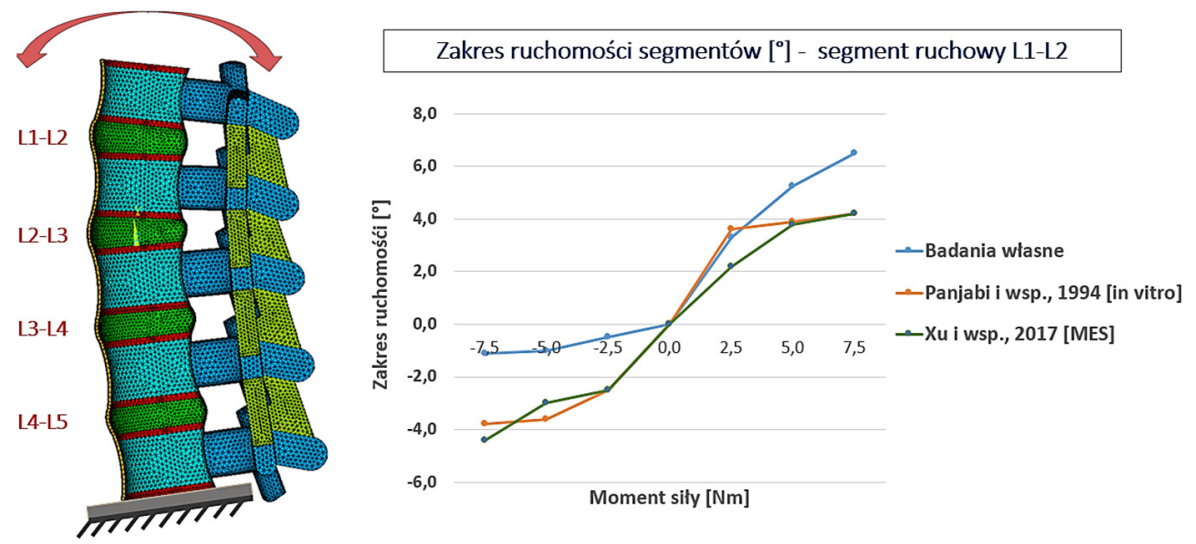

Rysunek 7. Porównanie wartości zakresu ruchomości kątowej segmentu L1-L2 z danymi literaturowymi w przypadku zginania (+) i przeprostu (-)

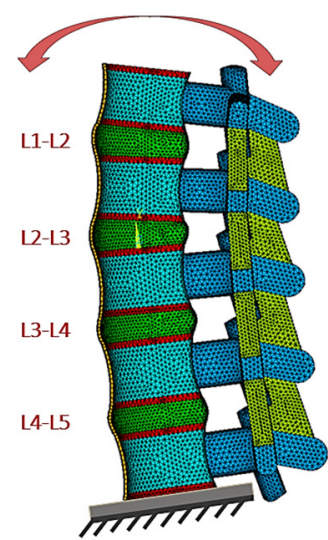

Zakres ruchomości segmentów [] - segment ruchowy L2-L3

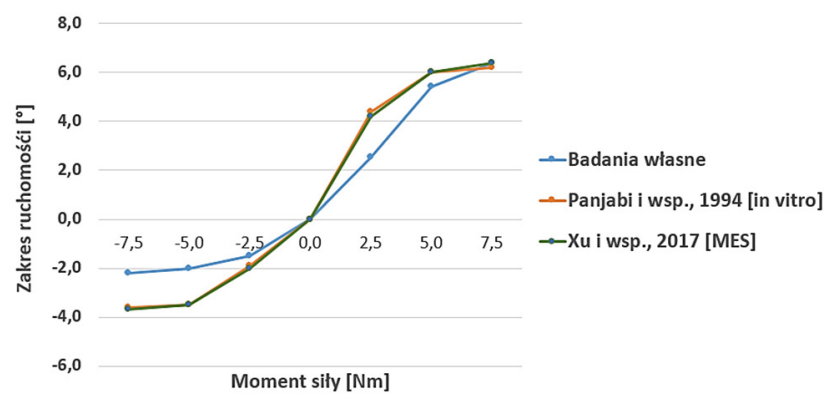

Rysunek 8. Porównanie wartości zakresu ruchomości kątowej segmentu L2-L3 $z$ danymi literaturowymi w przypadku zginania (+) i przeprostu (-) 

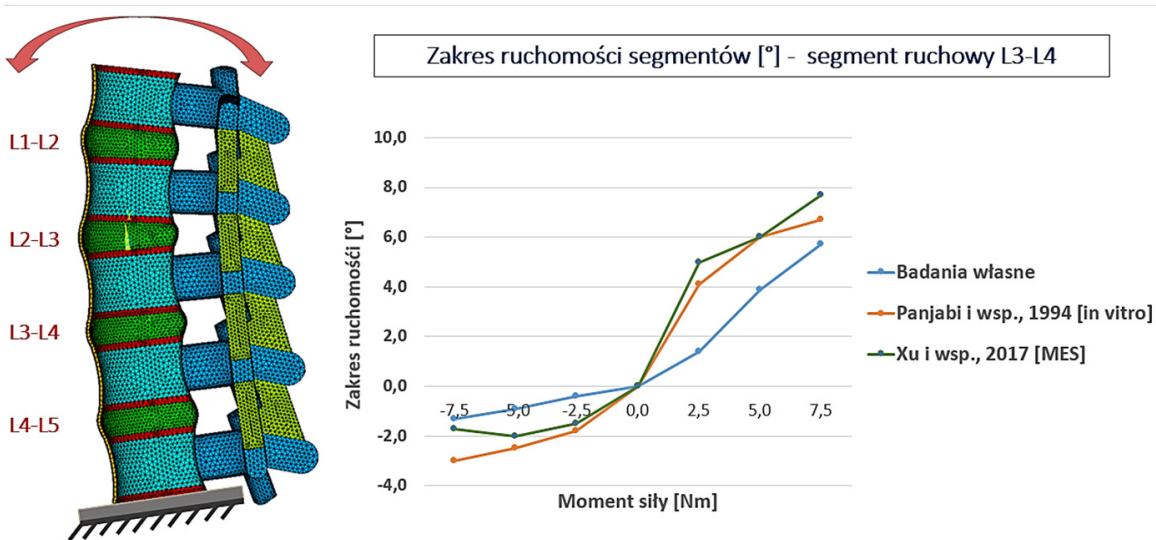

Rysunek 9. Porównanie wartości zakresu ruchomości kątowej segmentu L3-L4 z danymi literaturowymi w przypadku zginania (+) i przeprostu (-)
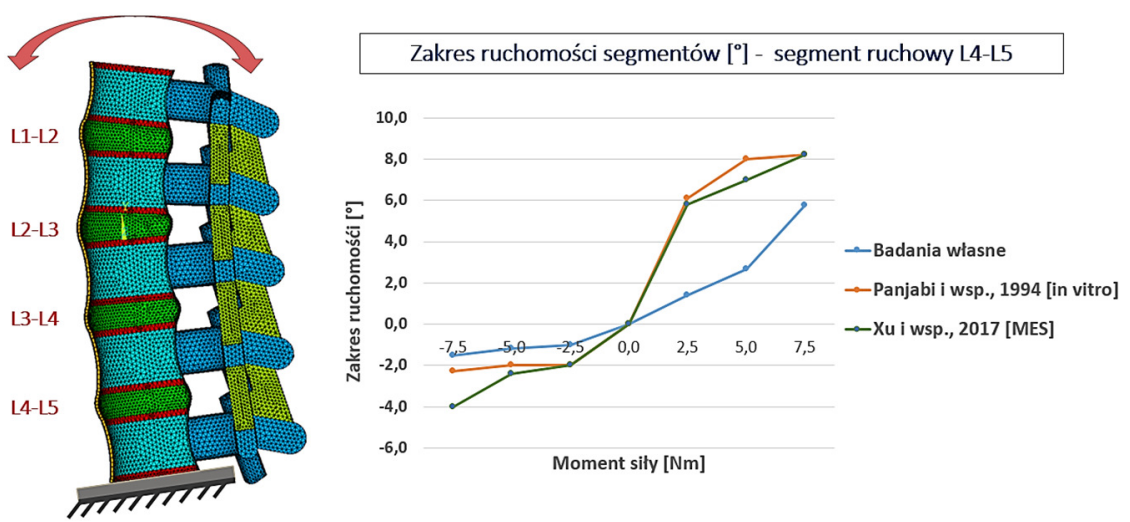

Rysunek 10. Porównanie wartości zakresu ruchomości kątowej segmentu L4-L5 z danymi literaturowymi w przypadku zginania (+) i przeprostu (-)

\section{Wnioski i podsumowanie}

Przeprowadzona walidacja przyjętych założeń dla modelu numerycznego odcinka lędźwiowego kręgosłupa pozwoliła na zweryfikowanie otrzymanych wyników z danymi literaturowymi. Na jej podstawie zaobserwowano, że otrzymane wyniki są zbliżone do wyników uzyskiwanych przez autorów innych prac badawczych (doświadczalnych i numerycznych) [8-14]. W związku z tym potwierdzono słuszność zastosowanych założeń dotyczących zarówno odwzorowania geometrii kręgosłupa jak również właściwości materiałowych. Dlatego też model numeryczny odcinka lędźwiowego może posłużyć do oceny wpływu stosowania różnych konfiguracji systemu stabilizacji transpedikularnej na wybrane parametry mechaniczne kręgosłupa. Przyjęta założenia odwzorowują zachowanie odcinka 
lędźwiowego i są odpowiedzenie do przeprowadzenia analiza na podstawie przygotowego modelu numerycznego.

\subsection{Ograniczenia}

W przygotowanym modelu geometrycznym odwzorowującym kształt odcinka lędźwiowego kręgosłupa, uwzględniono pewne uproszczenia poprzez usunięcie detali w geometrii kręgów. Założeniami upraszczającymi był również dobór parametrów materiałowych. Ze względu na to, że obciążenia działające na kolumnę kręgosłupa głównie przenoszone jest przez krążek międzykręgowych skupiono się na tym, żeby odwzorować jak najdokładniej jego strukturę. Stąd jądro miażdżyste i pierścień włóknisty opisane zostały nieliniowym modelem hipersprężystym Mooney-Rivlin'a. W macierzy pierścienia włóknistego dodatkowo uwzględniono też trzy warstwy o zróżnicowanym parametrach materiałowych oraz zmiennym nachyleniu włókien. Dokładność z jaką odwzorowano krążek międzykręgowy spowodowała, że tkanki kostne, więzadła oraz mięśnie opisano uproszczonymi liniowymi parametrami materiałowymi.

\section{LITERATURA}

1. DREISCHARF M., ZANDER T., SHIRAZI-ADL A., PUTTLITZ C., ADAM C., CHEN C., GOEL V., KIAPOUR A., KIM Y., LABUS K.: Comparison of eight published static finite element models of the intact lumbar spine: predictive power of models improves when combined together. Journal of Biomechanics, 47(2014), 1757- 1766.

2. LI Q.Y., KIM H.J., SON J., KANG K.T., CHANG B.S., LEE C.K., YEOM J.S.: Biomechanical analysis of lumbar decompression surgery in relation to degenerative changes in the lumbar spine-Validated finite element analysis. Computers in Biology and Medicine, 89(2017), 512-519.

3. XU M., YANG J., LIEBERMAN I.H., HADDAS R.: Lumbar spine finite element model for healthy subjects: development and validation. Computer Methods in Biomechanics and Biomedical Engineering, 20(2017)1, 1-15.

4. ZAHARI S.N., LATIF M.J.A., RAHIM N.R.A., KADIR M.R.A., KAMARUL T.: The effects of physiological biomechanical loading on intradiscal pressure and annulus stress in lumbar spine: a finite element analysis. Journal of Healthcare Engineering, 2017 (2017), 9618940.

5. SZKODA K., PEZOWICZ C.A.: Finite element analysis of fixation system influence on the thoracolumbar spine stability. Applied Mechanics and Materials, 821(2016), 685-692.

6. PANJABI M.M., OXLAND T., TAKATA K., GOEL V., DURANCEAU J., KRAG M.: Articular facets of the human spine. Quantitative three-dimensional anatomy. Spine, 18(1993), 1298-1310.

7. SCHMIDT H., GALBUSERA F., ROHLMANN A., ZANDER T., WILKE H. J.: Effect of multilevel lumbar disc arthroplasty on spine kinematics and facet joint loads in flexion and extension: a finite element analysis. European Spine Journal, 21(2012)5, 663-674. 
8. ANDERSSON G.B., ORTENGREN R., NACHEMSON A.: Intradiscal pressure, intra-abdominal pressure and myoelectric back muscle activity related to posture and loading. Clinical orthopedics and related research, 129(1997), 156-164.

9. WILKE H.J., NEEF P., CAIMI M., HOOGLAND T., CLAES L.E.: New in vivo measurements of pressures in the intervertebral disc in daily life. Spine, 24(1999)8, 755-762.

10. SATO K., KIKUCHI S., YONEZAWA, T.: In vivo intradiscal pressure measurement in healthy individuals and in patients with ongoing back problems. Spine, 24(1999)23, 2468.

11. ROHLMANN A., ZANDER T., RAO M., BERGMANN G.: Realistic loading conditions for upper body bending. Journal of Biomechanics, 42(2009)7, 884-890.

12. WOOD K.B., KOS P., SCHENDEL M., PERSSON K.: Effect of patient position on the sagittal-plane profile of the thoracolumbar spine. Journal of spinal disorders, 9(1996)2, 165-169.

13. BRINCKMANN P., GROOTENBOER H.: Change of disc height, radial disc bulge, and intradiscal pressure from discectomy. An in vitro investigation on human lumbar discs. Spine, 16(1991)6, 641-646.

14. PANJABI M.M., OXLAND T.R., YAMAMOTO I., CRISCO J.J.: Mechanical behavior of the human lumbar and lumbosacral spine as shown by threedimensional load-displacement curves. The Journal of bone and joint surgery. American volume, 76(1994)3, 413-424.

\section{Podziękowania}

Obliczenia wykonano przy użyciu zasobów udostępnionych przez Wrocławskie Centrum Sieciowo-Superkomputerowe (http://wcss.pl), grant obliczeniowy $\mathrm{Nr} 423$. 
